contents are difficult to fault. Indeed, because the authors consulted widely with colleagues elsewhere and generously allowed them to use their developing material, many already appreciate this. But they also know that successful introduction of such courses depends on the willing collaboration of many people, teachers and administrators as well as students, in the medical school concerned. The manual is an excellent account of the basic requirements for practice skills teaching, and it is full of good ideas which others will find well worth trying out. But it is not, nor do its authors intend it to be, any substitute for continuing patiently to work out, with colleagues and students in your own medical school, where, when and how ethics, law and communication skills teaching can be integrated most acceptably and effectively into what for the foreseeable future seems likely to be an ever-changing undergraduate curriculum.

KENNETH M BOYD Research Director, Institute of Medical Ethics and Senior Lecturer in Medical Ethics, Edinburgh University

\section{Reproductive Technology and Rights}

\author{
Edited by James $M$ Humber and \\ Robert F Almeder, Totowa, New \\ Jersey, Humana Press, 1995, 168 \\ pages, $\$ 44.50 \mathrm{hb}$.
}

Fathers should not be legally required to provide child support. Infertile couples have no basic right to medical assistance in reproduction. Killing two fetuses in a quadruplet pregnancy is morally justifiable. A pregnant woman who knows her fetus is seriously disabled has a duty to abort it.

These provocative proposals illustrate the challenge, topicality and occasional novelty of the eight philosophical and ethical essays in the thirteenth annual volume of Biomedical Ethics Reviews. It is divided into three parts, dealing respectively with abortion, in vitro fertilisation (IVF) and handicapped fetuses and children.

In the first part, Stephen Hales and James Humber debate the alleged inconsistency between three philosophical assertions: (1) Women have an unqualified right to abortion; (2) Men and women have equal rights and duties; (3) Men have an absolute duty to support their children once born. Hales argues in "Abortion and fathers' rights", that because a woman's right to abortion is a right to avoid duties (of child care), and because a father cannot for biological reasons have the same right to avoid duties, the statements are inconsistent and the father should not be legally required to provide child support.

Humber responds, in a chapter entitled "Maternity, paternity and equality" that "once a woman becomes pregnant, an immediate inequality is created between her and her sex partner" (page 36). The mother's duty, if the child is born, far exceeds the father's obligation to contribute financial resources; she must provide for "everything else that the child requires": night feeds, potty training, cooking, cleaning etc (page 38). The right to choose abortion is her means to reinstate equality: "[W]e must treat unequals [women and men] unequally if we are to satisfy the demands of justice" (page 37). But, replies Hales, in "More on fathers" rights", these "burdens of childbearing . . . are not properly considered harms or burdens at all ... [The mother] freely chose the consequences of childbearing . . ." (page 47).

The second part focuses on in vitro fertilisation. Under the chapter heading "Ethical considerations in the multiplication of human embryos", Kathleen Ganss Gibson and Joe Massey examine ethical issues in the use of blastomere separation (splitting a 2-, 4- or 8-cell embryo to produce two identical embryos) and cloning (replacing the nucleus of an egg with another embryonic nucleus) in IVF treatment and embryo research. The physical risks to the embryo are far greater in the latter but one's conclusions will be "dramatically different" if the embryo is, or is not, "perceived as a human being" (page 68).

Leonard Weber considers resource issues in relation to IVF and argues that infertile couples have no basic right to medical assistance for reproduction ("In Vitro fertilisation and the just use of health care resources"). People may have the same negative rights ("a right to be left alone"), he says, but "it is something quite different to claim that we all have a basic right to medical treatment or technology simply because we think it would meet our needs or wants" (page
76). "A just health care system" must consider not only need or benefit but also "alternative uses of resources" (page 78). Becoming a parent is not necessary to "meet basic human needs" (page 84) so it is not unjust to limit access to those who can gain maximum benefit, namely (according to Canadian "evidence-based medicine") women with blocked fallopian tubes (page 87).

Walter Glannon assesses the morality of fetal reduction in a multiple pregnancy ("The morality of selective termination"). He argues that it is morally permissible on consequentialist grounds to reduce the number of fetuses in a multiple pregnancy. Multiple pregnancies present increased risks for mother and child and "fetal reduction by two in quadruplet pregnancies is the most viable way to minimise complications and to thereby ensure a reasonable quality of life for the pregnant woman and the two fetuses who are brought to term" (page 97). Consequentialism provides a better ethical guide than the "deontological intuitions concerning the loss of potential and actual lives" (page 93) of "virtue theorists, moral pluralists and proponents of the Sanctity of Life Principle" (page 97).

The third part of this book contains two essays linked by the theme of handicap. The first focuses on fetal abnormality. Bambi Robinson ("On a woman's obligation to have an abortion") states that a woman who knows she is pregnant with a fetus that has a serious problem, such as Tay Sachs disease, has an obligation to abort it. "[The] baby will know little other than pain or suffering until its death" (page 116) and "it is wrong to deliberately inflict protracted suffering on a sentient being. Second, the emotional and physical costs to the parents are less in the case of a second trimester abortion than in bringing such a seriously impaired child into the world" (page 116), she says.

The final essay concerns children born with a handicap, in this case dyslexia. Richard Hull ("The just claims of dyslexic children") puts forward arguments based on John Rawls's Original Position for parents of handicapped children seeking to gain resources for their child Although "the basic idea of fairness here is equal distribution of liberties and of economic goods . . . Rawls recognises that . . . those whose needs are greater may be better served by unequal distributions" (page 143).

This brief summary indicates the 
substance and range of these essays, which are stimulating and highly readable, both for specialists and general readers. One may, of course, take issue with particular points: does abortion really constitute a right to avoid duties? Does it matter if men and women have different moral and legal rights in relation to abortion? Is the denial of the father's right to prevent an abortion not due to this being a "positive" right (requiring action by another person) rather than a "negative" or civil right (of the type discussed in Weber's essay)? If Tay Sachs disease means that "the child's basic interests are all thwarted" (page 127) (and that is perhaps debatable), that may justify an abortion but can one take the further step of imposing a duty on the mother to abort? However, the intellectual response provoked by the essays is part of the enjoyment of reading them!

LOANE SKENE Associate Professor and Director of Studies, Health and Medical Law, Law School,

The University of Melbourne, Australia

\section{Changing Conceptions of Motherhood}

Edited by Derek Morgan, London, British Medical Association, 1996, 74 pages, $£ 6.95$.

\section{Considering Surrogacy}

London, British Medical Association and Human Fertilisation and Embryology Authority, 1996, 11 pages, $£ 5.20$.

"Six weeks after his birth, George and Dianne knew that little Jack would soon be theirs legally. They were all grateful for the helpful advice and direction that their general practitioner had given them and for showing Tracy (the partial surrogate) how to do the artificial insemination herself. Dianne hoped desperately that Tracy (who of course was the legal mother until the parental order could be obtained), would not change her mind and decide to keep Jack as she knew she was entitled to do under the terms of the Human Fertilisation and Embryology Act (1990), by which instrument no surrogacy arrangement was enforceable. George and Dianne had been surprised, that, despite having lived together for the best part of ten years, they were advised to become married well before the birth otherwise they would not be able to request the parental order making him their son legally. It also seemed bizarre to Dianne that despite Tracy's estranged husband really having nothing much to do with the whole affair, he was still Jack's legal father until the parental order was obtained - at least he didn't object, which really would have made things diffcult! At night she often wondered how Jack would feel at the age of 18 when, even if she and George decided to hide the terms of his birth, he could seek out the registrar of births and obtain his birth certificate on which was written the name of his birth mother. Would he still regard Tracy as his real mother, or would the fact that she, Dianne, had brought him up as his social and legal mother really count? They were still undecided what to do. Perhaps she'd discuss it again with the counsellor whom her GP had arranged for her.

"How mean it was that according to the Surrogacy Arrangements Act (1985), she couldn't pay Kim and the other members of the Womb with a View Club as she knew that would have been illegal. Nevertheless she felt a great debt to them for arranging for her to meet Tracy and for her to be the surrogate, especially since she knew that she could not have advertised for her in the newspaper - no editor would have touched it with a barge pole as that too would have been illegal under the Act. She hoped that the $£ 10,000$ that she gave Tracy would compensate her adequately for her having to give up her job, and for all the travelling to and fro for antenatal care. Strange how some people thought that no money could change hands in a surrogacy arrangement but then she wasn't being paid, it was just 'reasonable expenses'."

How well informed George and Dianne were - thanks to the help of their knowledgeable general practitioner, who clearly had read Changing Conceptions of Motherhood - the Practice of Surrogacy in Britain. This is not a rip-roaring read, nor a taxing ethical discussion about surrogacy, nor is it meant to be. It is a considered and factual account of the practice of

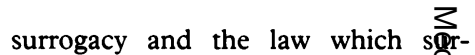
rounds it, and of its medical aspects, plus a useful discussion of the psyclogical aspects of surrogacy and need and place of counselling.

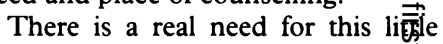
book, as may be seen from the preceding scenario. Many practition ess, whether general or specialist, find 鹿e whole area confusing, and to many so fraught with legal traps as to makeit a method of treatment well worth steying clear of. This too is the complaint of many women, who, as a last resørt, would like at least to discuss the posgibility but have no idea where to tuw, as their own health professionals क्ञ⿰冫欠 scared and ill-informed. The bợk clarifies terminology such as parfial and full surrogacy; who is the father; parental orders and adoption; bioh registration, and the terms of the A $\overrightarrow{g t s}$ relevant to the practice of surrogaey. The amended Surrogacy Arrangements Act (1985) is included for god measure. Despite at times being a $\Phi_{i t}$ legally turgid, it should be mandat $\bar{x} y$ reading for all involved with the dekivery of assisted conception and shoytd be available in libraries for those wis ing to clarify the issues.

Help is at hand for the consuner too. The BMA/HFEA have pubsd jointly an informative 11-page bøolfest which is derived from the above bogk, but has been simplified in a questiognand-answer style to make it useful-to women considering surrogacy. As with the book, it deals with the legal position, the status of the child, parental orders and criteria for becoming a surrogate mother. Questions to do th the involvement of medical professionals, the benefits of counselling and the health risks are all raised qudd answered, as is the implication for gie child and others. Although the läguage has been highly simplified I believe it will still be too difficult for many who are in greatest nesd. Nevertheless its general usefulns cannot be doubted. It will be of be fit not only to those considering surrogacy, but to anyone simply interested in what surrogacy is about and whrtit entails. It will also be useful to sogre who are more peripherally involyed health care professionals, and inde्ed to students who wish to have a quamek preview of the issues in order to decide if more in-depth reading is requirgd.

PETER R BRAUBE

Professor of Obstetrics and Gynaecolgy

United Medical and Dental Schoolsof Guy's and St Thomas's Hospitals,

London 